Bioethics: an export product? Reflections on hands-on involvement in exploring the 'external' validity of international bioethical declarations

Dr Mairi Levitt

Department of Philosophy

Furness College

Lancaster University

Lancaster

LA1 4YG

email: m.levitt@lancaster.ac.uk

tel. +44(0)1524-593596

fax:+44 (0) 1524592503

Prof. Dr. Hub Zwart

Radboud University Nijmegen

Faculty of Science - Institute for Science, Innovation \& Society

Department of Philosophy and Science Studies - Centre for Society \& Genomics P.O. Box 90106500 GL Nijmegen

The Netherlands

email.h.zwart@science.ru.nl

tel. +31 (024) 3652038

fax $+31(024) 3652263$ 


\title{
Bioethics: an export product? Reflections on hands on involvement in exploring the 'external' validity of bioethical declarations
}

\author{
Abstract: \\ As the technosciences, including genomics, develop into a worldwide, global \\ phenomenon, the question inevitably emerges whether and to what extent bioethics \\ can and should become a globalised phenomenon as well. Could we somehow \\ articulate a set of core principles or values that ought to be respected worldwide and \\ that could serve as a universal guide or blueprint for bioethical regulations for \\ embedding biotechnologies in various countries? This article considers one universal \\ declaration, the UNESCO Declaration on Bioethics and Human Rights (2005), to \\ which a special issue of Developing World Bioethics was dedicated. General \\ criticisms made there are that the concepts used in the Declaration are too general and \\ vague to generate real commitment; that the so-called universal values are not \\ universal; and, that UNESCO should not be engaged in producing such declarations \\ which are the domain of professional bioethicists. This article considers these and \\ other criticisms in detail and presents an example of an event in which the Declaration \\ was used: the request by the Republic of Sakha, in Siberia, for a UNESCO delegation \\ to advise on the initiation of a bioethics programme. The Declaration was intended to \\ provide an adequate "framework of principles and procedures to guide states in the \\ formulation of their legislation, policies and other instruments in the field of \\ bioethics" (article 2a) The Declaration was produced, and principles agreed upon, in \\ an interactive and deliberative manner with world-wide 'expert' participation. We \\ argue that the key issue is not whether the general principles can be exported \\ worldwide (in principle they can), but rather how processes of implementation and \\ institutionalisation should take shape in different social and cultural contexts. In \\ particular broader publics are not routinely involved in bioethical debate and policy- \\ making processes worldwide.
}




\section{Introduction}

In an era of globalisation, the technosciences, including genomics, are quickly developing and evolving into a worldwide, global phenomenon. Therefore the question inevitably emerges whether and to what extent bioethics can and should become a globalised phenomenon as well. ${ }^{1}$ Could we somehow articulate a set of core principles or values that ought to be respected worldwide and that could serve as a universal guide or blueprint for bioethical regulations for embedding biotechnologies in various countries? International organisations such as UNESCO, but also the Human Genome Organisation's Ethics Committee (HUGO), could play an important role in this respect. The UNESCO declarations on genomics (notably "The Human Genome and Human Rights" Declaration and the "Declaration on Bioethics and Human Rights") can be regarded as interesting examples of such an effort. $^{2}$

As one of us has pointed out elsewhere, however, this role is far from uncontested. ${ }^{3}$ In the editorial to a special issue of Developing World Bioethics, the UNESCO declaration has been fiercely criticized. ${ }^{4}$.. One of the objections raised was that the concepts used in this document are too general and vague to generate real commitment. Moreover, it was argued that the "values claimed to be universal in this document are, in actual fact, nothing of the sort" ${ }^{5}$, and this notably applies to concepts such as 'human rights' and 'dignity'. A third important criticism raised by the authors of the editorial was that UNESCO is actually trespassing on other people's domains. In their opinion, UNESCO is not supposed to set up such declarations at all. They argue that "whole articles deal with matters of informed consent in biomedical research and therapeutic practice. It is entirely unclear why UNESCO should concern itself with such a matter." ${ }^{6}$ Such activities, they write, are the domain of other organizations or, better still, should be left to the "professional bioethicists". In short, UNESCO was denied the competence and qualification to discuss these things.

A second example of an international platform engaged in this type of work is the Human Genome Organisation's (HUGO) Ethics Committee, chaired by Ruth Chadwick ${ }^{7}$. This committee has published an impressive series of statements on core issues concerning the ethical, legal and social aspects of genomics, including DNA Sampling (1998), Cloning (1999), Benefit Sharing (2000), Gene Therapy Research (2001), Human Genomic Databases (2002) and Stem Cell Research (2004). Its latest statement concerns pharmacogenomics (2007) ${ }^{8}$. No doubt, the same kind of criticism that has been levelled at the UNESCO declaration could be directed towards these HUGO statements as well.

Having been active ourselves in a series of efforts to promote a more international and trans-cultural approach in bioethical discourse, we believe that this is more than just an academic dispute. The quality and status of international bioethical declarations may come to play an important role in addressing the ethical dilemmas emerging in the context of international coordinated research efforts now and in the near future. Therefore, we want to take the dispute outlined above a step further by exploring the issue in two directions. First of all, we would like to assess what might be called the internal validity of the UNESCO declaration. To what extent can the criticisms that were made be regarded as fair and sound? Secondly, we want to assess the external validity of the declaration. This is done by reflecting, autobiographically as it were, on our professional experiences as 'ELSA genomics experts' involved in bioethical deliberations on an international level. The hard core 
of these experiences is formed by a unique bioethical expedition we joined, organised under the auspices of UNESCO, which set out to assess the moral soundness and quality of a genetic screening programme that was carried out among indigenous people of North-East Siberia. What role can international bioethical declarations play in such a situation? In this way we move from the crucially important task of desk analysis of arguments and concepts to the complementary but equally important task of critical reflection on how ethics actually works in practice.

\section{The UNESCO declaration and its criticism reconsidered}

An important line of criticism directed against international bioethical declarations such as the one issued by UNESCO is that its core principles, such as solidarity, equity and beneficence, often remain relatively vague, while one may question the extent to which these principles can really be regarded as universal, from a bioethics perspective. A first important question is, whether this type of criticism is doing justice to the genre involved, to the type of document we are dealing with. Although the meanings of some of the key concepts used in this type of documents have been elaborated in intricate ways by academic bioethicists in their journals, they are likely to play a somewhat different role in the context of international policy development. Through international dialogue on various levels and in various contexts, and building on the conceptual efforts of professional bioethicists, declarations intend to contribute to the process of developing the basic framework of a universal bioethics. Its basic objective is to set up a network of concepts that may support the difficult but indispensable task of building international policies for science governance (and this includes genomics governance). At a time when genomics research is spreading globally at a high pace, this, one could argue, becomes an urgent task. Undoubtedly, academic bioethics has an important and critical contribution to make to this process, but this does not deny the relevance and value of international declarations as such.

Since the UNESCO Declaration is criticised for conveying a Western ideological bias, it is relevant to consider the process by which the declaration was produced and the numbers of individuals and organisations involved. The mandate for the declaration, from the General Conference of UNESCO in 2003, “considers that it is opportune and desirable to set universal standards in the field of bioethics with due regard for human dignity and human rights and freedoms, in the spirit of cultural pluralism inherent in bioethics" ${ }^{9}$. There was a three-month pre-drafting consultation which involved a written consultation with member states and a meeting of the International Bioethics Committee (IBC) to decide on the declaration's scope and structure. After the drafting process (April 2004 to January 2005) there was another consultation (January to September 2005) including national and regional meetings of experts. The IBC has 36 members with a balanced geographical representation and cultural diversity. Some countries sent members with expertise in a particular area, for example, life sciences, social science, law, philosophy or education. The IBC held a 3-day session with 200 participants from 70 countries to discuss the declaration and included representatives from a variety of governmental and non-governmental organisations and National Bioethics Committees. ${ }^{10}$.

The opening sentence of the mandate (above) tackles the obvious problem with a declaration intended to be acceptable to the 192 member states of UNESCO; how to gain agreement on any universal standards among diverse cultures. What is 
the 'spirit of cultural pluralism'? In the preamble the point is made that culture should not be appealed to "at the expense of human rights and fundamental freedoms". Taking the example of female circumcision, the United Nations condemns it as violating the rights of the child. There has been discussion of symbolic female circumcision to fulfil the cultural role of preparing girls for marriage, without the accompanying physical and psychological damage. There is an awareness of the dangers of simply condemning a practice without understanding its cultural role, but of course there may be ethical objections to continuing a symbolic practice, depending on what it is symbolising.

In the special issue of Developing World Bioethics mentioned above, the editorial criticised the whole enterprise because the declaration contains principles that are considered as being not universal. In particular dignity is not regarded a universal principle. The point made is that there is a European bias. Indeed, "European enlightenment philosophy pervades the declaration". ${ }^{11}$ Yet, in the first consultation stage of the declaration a questionnaire was sent out to member states asking which fundamental principles should be reaffirmed in the declaration. The values which all respondents agreed on were dignity, equality, non-discrimination and respect for privacy. Out of 67 responses there were eleven from Africa, 8 from Asia and the Pacific, 10 from Arab states, 6 from Latin America and the Caribbean, 10 from Central and Eastern Europe and 21 from Europe and America. Although an answer to a questionnaire is not strong evidence that fundamental principles are universally shared, it at least indicates that dignity as a concept is widely recognisable. There were specific references to dignity in written comments on the draft, by, for example, Indonesia and Paraguay. ${ }^{12}$. For the purposes of a Declaration intended to influence governments throughout the world, the recognition and acceptability of the fundamental principles by all countries is crucial.

The evidence against the universality of dignity offered in the editorial is an article entitled "Dignity is a useless concept" by the US bioethicist Ruth Macklin. ${ }^{13}$. She argues that dignity means no more than respect for autonomy. However, she notes that people refer to treating a dead body with dignity and argues that "This situation clearly has nothing to do with respect for autonomy since the object is no longer a person but a cadaver". An alternative view would be that since cadavers cannot have autonomy, perhaps dignity is not the same as autonomy and so may be used about people without autonomy, including the dying, the very elderly, and about ex-people. As Häyry and Takala point out, dignity is not defined in the declaration, nor is its relationship to other principles explained. ${ }^{14}$. This is true of other principles, that are "proclaimed" in the Declaration rather than discussed. As Benatar and Williams both point out in their respective contributions to the special edition, the Declaration is a compromise and the principles are indeed rather vague. ${ }^{15}$. This is, of course, a common criticism of principlism and of the four principles of medical ethics in particular. The principles are necessarily vague in an international declaration in order to secure agreement by all member states. The declaration is not legally binding and the principles "are to be respected", "should be given due regard" rather than representing obligations. This does not deny that they could function as guidelines for reviewing or reorganising research practices, for instance when a country is devising a national system for ethical review of medical research for the first time. Since all ethical principles are interpreted differently within and between social and cultural groups and over time, precise definitions, if acceptable, could be too specific to the circumstances when a Declaration is made and therefore not able to be adapted to an unforeseen development. 
Landman and Schüklenk criticise particular articles as "untenable".

Referring to article 3.2 they argue: "Surely it is untenable to say individual"s interest should always have absolute priority over societal interest" ${ }^{16}$ op cit, v). They give the example of public health where it may be necessary to have a proportionate restriction on individuals for the social good and so "nobody in the real world would take article 3b seriously as it stands." ${ }^{17}$. However article 3.2 actually reads "the interests and welfare of the individual should have priority over the sole interest of science or society" (authors' emphasis), but in their comments, the crucial term "sole" is left out. Subsequently, Landman and Schüklenk state that article 4, if adopted, "would render pretty much all biomedical research impossible."18 The article reads, "Benefits to participants must be maximised and their possible harms minimised". The editors argue that maximising individual benefit cannot be a primary objective. The primary objective of medical research would be to test a drug or a treatment. Although this is obviously right, we do not see why in doing so, benefits should not be maximised and harms should not be minimised. Otherwise, how would you obtain fully informed consent for the trials? The claim that "most researchers and research ethics committees would disregard" the clause would, if true, make it difficult to find healthy volunteers for research, which is apparently refuted by actual practice.

The authors also disagree with Article 11 as there can be no discrimination against individuals and groups "on any grounds", whereas there may be good grounds to discriminate against, say people with racist views. However, the clause does not say "on any grounds." ${ }^{19}$. It says "in violation of human dignity, human rights and fundamental freedoms". The example given, of a racist applying to be an equal opportunity officer, would be covered by this clause.

The crux of Landman's and Schüklenk's dislike of the UNESCO declaration, however, is that an official organisation is moving into bioethics and "Bioethics, as we understand it, is an academic discipline and not a playground for government appointed politician-experts to muse on in an inconsequential and arguable not very sophisticated manner about ethics.” ${ }^{20}$. Ironically, this line of reasoning is not unlike the type of criticism professional bioethicists themselves often receive when they start 'meddling' (as members of research ethics committees for instance) with affairs that, according to some, could better be left to the professionals (in this case, biomedical researchers). Yet, we would argue that bioethics is not only an academic discipline. In fact, bioethicists often want to use their academic credentials to influence policy and practice, for example Schuklenk in his work in the area of HIV and AIDS.

Academic bioethicists are not the target audience for this declaration, governments are. Henk ten Have, Director of the Division of Ethics of Science and Technology responsible for the Declaration, is quoted as saying that the Declaration does not aim to "promote academic bioethics". UNESCO aims to use its guidance in order to "educate healthcare professionals and young scientists in ethics, to establish ethics committees, and create an infrastructure for bioethics" ${ }^{21}$. The declaration seeks to encourage ethical review of scientific and medical research, consent procedures for research involving human beings, public engagement and debate around bioethical issues. Although it may be doubtful whether any group of bioethicists would agree on what constitutes a sophisticated argument, the intention of the UNESCO document was to act as a basis for member states to create their own framework for ethical review and public involvement. For this purpose the 
publishing of pamphlets, disparaged by Landman and Schuklenk, is more appropriate than academic journal articles.

A final criticism considered here, made by Benatar, is that it is a weakness that the Declaration concentrates on human beings. As Benatar himself points out, however, this is following the wishes of member countries when the first consultation was carried out. ${ }^{22}$. Critics could argue that humans are given privileged status, and they are, but the declaration as it stands does not preclude the elaboration of similar documents addressing issues of animal ethics or environmental ethics. The ideological framework is clearly stated to be human rights and in a declaration addressed to States the focus is on the protection of the individual, over the sole interest of science and society. This would be problematic in an international declaration if human rights could be shown to have a Western or European bias. However, while human rights may not be a framework commonly used by 'professional bioethicists". ${ }^{23}$, it is frequently used by international conventions and declarations and many non-western countries subscribe to human rights legislation. In the special issue from which this criticism is taken, Nie Jing Bao argues that a human rights perspective is not at all incompatible with Confucianism or Taoism. ${ }^{24}$ As we said, the declaration is addressed to a broader audience than "professional bioethicists" and is intended to be "comprehensible and accessible to everyone.....addressed to both Member States and to researchers, scientists, decision-makers and citizens. ${ }^{25}$

\section{Lack of attention to social/cultural context}

It is a very common criticism of bioethics in general that it pays insufficient attention to social and cultural contexts. Is it ethically legitimate to argue that certain policies 'ought' to be implemented in places where a bioethical infrastructure has been inexistent? Bioethicists might argue in journal articles that people ought to be able to sell their organs or that sex selection ought to be allowed, but if such arguments are to effect policy, should they take into account the political and cultural situation in any particular society? Could we argue in favour of commercialisation on theoretical grounds without ensuring that those who are selling organs are also able to afford the necessary immune suppressant drugs? Can we argue against sex selection in a culture where giving birth to sons or daughters affects people's prospects in terms of poverty or prosperity? Or can we argue in favour of sex selection (on the basis of 'reproductive autonomy' for example) even when this would result in a skewed sex ratio, with long term social consequences? The declaration is only setting a framework within which different societies and cultures can operate, provided they advance anti-discrimination and benefit sharing. There will not be the same arrangements everywhere. Still, it is stated in the Declaration that the socio-cultural context cannot be appealed to in order to legitimise marginalization or exclusion. The importance of public health and environmental provisions is also recognised (article 14).

Rawlinson and Donchin ${ }^{26}$ argue that the declaration does not recognise disparities of power and wealth. Yet, although it does not specify particular inequalities, it does mention vulnerable groups and women and children, who have unequal access to resources in many countries. The point of the universal declaration is to assert that while in any particular society there will be structural inequalities, everyone has human rights and in all societies "progress in science and technology should advance the improvement of living conditions and the elimination of marginalisation and exclusion of persons on any grounds” (article 4). Landman and 
Schuklenk are concerned that characterising groups/people as vulnerable could be harmful to others considered less vulnerable. However, who the vulnerable groups are is an empirical question in any society and could change over time. It is of course a common complaint of a dominant group that they are discriminated against when there are special measures for a less powerful group. Whether or not the complaint is upheld should be a matter of examining the evidence.

Yet, this type of discussion is bound to remain theoretical and academic as long as it takes place on this rather abstract and general level. In order to further develop the discussion, we would need to study specific examples of how such declarations function in specific contexts. By doing so the 'external' validity of international declarations can be tested empirically as it were. We ourselves have been involved in, and have been greatly intrigued by, the following example of an effort to 'export' bioethical principles beyond their usual sphere of influence. And we would like to further develop this debate by drawing on our own experiences.

\section{UNESCO delegation to Siberia}

In May 2005 we were invited (as ELSA genomics experts) to join a UNESCO delegation for a site visit to Yakutsk, Capital of Sakha (also known as Yakutia), Siberia, where a genetic screening programme for myotonic dystrophy was being set up, - a hereditary muscular disease that is prevalent among indigenous people in Northern Siberia. This screening programme was also of interest in the context of the famous Human Genome Diversity Program, headed by Luca Luigi Cavalli Sforza ${ }^{27}$ and devoted to studying early human history and migration on the basis of genomic data derived from populations living today, thereby updating information that was previously provided by linguistics, ethnography, anthropology, palaeontology and archaeology. The research is notably based on genes coding for blood types (A, B, O and Rh) as well as on mitochondrial DNA ('Eve') and the Y chromosome ('Adam'). Eastern Siberia (notably its indigenous population) is of some interest in this respect because it must have constituted part of the bridge that allowed Asian populations to migrate (in three separate waves) into America. The HGDP regards genomes of living individuals (notably of indigenous populations) as deposits of DNA, as bioarchaeological files so to speak, so that DNA analysis may provide genetic snapshots of human diversity and history before some of these 'endangered populations' disappear for good. Yakutia is a sparsely populated area in the permafrost regions of Siberia, whose inhabitants are mainly dependent upon fishing. Diamond mining (recently privatised) is its sole core industry.

Our job, invited as ELSA experts in the domain of genomics, was to assist in the process of assessing benefits and risks of genetic screening in Yakutia. Basically, we attended a conference devoted to "Problems of the gene pool preservation of indigenous people of the North”. The workshop's main objective was to establish an ethics committee as well as a bioethics training module for monitoring the screening programme.

On the first day of the conference, some of the ongoing research and screening projects (including lectures on the diversity of mitochondrial DNA and Y chromosome lineages in populations in Yakutia) were presented while on the second day the focus shifted towards the ethical domain. The workshop was organised by the local UNESCO unit in collaboration with UNESCO Paris. UNESCO's involvement was motivated by its objective of "enshrining" universal declarations, such as the one on Bioethics and Human Rights, in which it is recognized that scientific programmes 
may particularly affect vulnerable indigenous and local communities. In UNESCO declarations it is stated that screening activities should be conducted on the basis of prior, free and informed consent, while benefits resulting from scientific research should be shared with society (for instance in the form of diagnostic facilities or support for health services). At the end of the workshop a declaration was accepted stating that an ethics committee was to be established consisting of members from various backgrounds and that the work of the committee should be supported by an on-site training programme.

Although this visit constituted a unique experience, it also raised a number of questions. First of all, the language used by local politicians and physicians during the discussions was at times uncannily reminiscent of what we in the West would refer to as eugenics. One politician for instance proudly announced that the screening programme for myotonic dystrophy would 'cleanse the gene pool", thus improving the health conditions of a population that had to survive under harsh climatologic circumstances. This raised questions on our part concerning issues such as individual and free informed consent. On the other hand, who were we to question the validity and quality of their procedures? Could 'our' bioethical views and principles simply be exported? In the middle of Yakutsk, a rather desolate and isolated town mainly consisting of quickly deteriorating concrete buildings, an impressive hospital had been built, funded by the diamond industry, whose very architecture seemed rather intimidating, although it could also be interpreted as benefit sharing in the sense of providing people who participated in the screening programme with health facilities.

We also noticed that it was difficult to really enter into a discussion of a deliberative, 'Western' type, asking and responding to critical questions. Besides the language problem (only a limited number of the people we met spoke either English, German or French so that in most cases we had to rely on the services of an interpreter, trained and recruited by the diamond company), we noticed a cultural divide as well: posing critical questions seemed somewhat at odds with local conventions and was apparently considered impolite. Rather, deliberations assumed narrative forms, exchanging anecdotal information over diner, invariably consisting of raw fish, horse tripe and vodka. Finally, last but not least, we felt uneasy about our own role, about the possibility that our very presence would serve a symbolic function, that it could be interpreted as legitimisation the project, - an international expert committee reviewed the programme, therefore its ethical permissibility seemed safeguarded. This was underlined by the fact that contrary to what was emphatically promised, there has never been a follow-up.

Interestingly, the kinds of questions we ourselves had with regard to our visit were not the questions addressed by the critics of UNESCO declarations cited above. In our view, the issue was not whether or not informed consent or human dignity can be meaningful and valid ethical principles at all, - they obviously can. Our worries and concerns could easily be articulated in these terms, notwithstanding the intricate bioethical discussions concerning the precise meaning of these terms that take place in analytically oriented bioethics journals. Our basic concerns rather had to do with power issues and procedural issues than with conceptual ones, with the power plays we had somehow entered, the meaning and impact, not of the terms we used, but rather of our very presence. In bioethical discussions the focus often tends to be on the content and meaning of basic concepts, their conceptual validity. What tends to be neglected, but what we found much more relevant and important, are issues of implementation and institutionalisation. The question is not 'what is' dignity (for instance), but rather: how can principles such as dignity or informed consent become 
an integral part of research and screening practices, - and who should play a role in this implementation process (scientists, policy makers, ethicists, or rather the public at large?), notably in areas such as Yakutia where there is no such thing as a functioning bioethical infrastructure. How are ethical deliberations to be organised? For instance: the question is not whether our lectures on informed consent were conceptually adequate (we believe they were). Rather, the question was how did they function, what impact did they have, and, finally, how to involve the broader public in designing screening policies? While the workshop was attended by researchers, physicians, policy makers and bioethics experts, Sakha citizens as such were absent.

As was stated above, one of the strengths of the UNESCO declaration is that it is the outcome of a process of intricate deliberations. It was not written at the desk of a bioethics expert, but rather in an interactive manner. Its weakness no doubt is that besides ethicists only government representatives and NGOs were allowed to contribute to this process. In many European countries consultative processes to access lay knowledge and expertise are well established and routinely undertaken by governmental bodies and NGOs as well as under the European Union Framework programmes (e.g. European Commission, 2005; Nuffield Council on Bioethics; Human Fertilisation and Embryology Authority HFEA ${ }^{28}$.). In 2003 for instance, the HFEA (UK regulatory body) decided against allowing sex selection for non-medical reasons and admitted to having been influenced in their conclusions by the views collected in a representative poll as well as by responses to their public consultation. ${ }^{29}$ Interestingly, the HFEA was criticised by bioethicist John Harris ${ }^{30}$ for, among other things, accepting public hostility to sex selection "at face value". No doubt, the procedure adopted by the HFEA is still some way from a genuinely bottom up approach, since the public were asked to react to issues pre-framed by the HFEA. ${ }^{31}$. Nonetheless, the willingness to consider more interactive methods for designing regulations and declarations seems wide-spread. Could it be that in the future the production of statements will involve broader publics. Could 'bottom-up' methodologies be extended or extrapolated from the national to the international level in order to achieve these goals?

Reflecting on our experiences we may conclude that the Yakutia experience demonstrated for us in a rather vivid manner both the strengths and the weaknesses of international bioethical declarations. The Declaration could have been an appropriate tool for the regulation of biotechnologies in the sense that it provided a framework within which a country like Yakutia could devise specific arrangements. Thus, it constituted a starting point for a first assessment, a first exploration of unknown territory. The weakness was, however, that we did not come much further than that, and that a declaration, instead of giving impetus to a thorough reflection on emerging quandaries, may also be used as an instance of 'ethics theatre', setting the stage for an encounter that merely served ritualistic purposes. For indeed, in practice what was produced was yet another formal declaration rather than specific arrangements to embody the articles of the Declaration on informed consent, the right to refuse to take part in research, opportunities for pluralistic public debate and so on.

\section{From bioethics to public involvement?}

At this point we would like to introduce a second example, once again borrowing from personal experience. On November 2007 a delegation of bioethics experts from China visited the Netherlands. The highlight was a Chinese-Dutch symposium on the societal aspects of genomics in Utrecht, November 5 . Contributions from the 
Netherlands tended to focus on cultural and ethical differences between West and East. In a recent report, for instance, Van den Belt and Keulartz ${ }^{32}$ had noticed that, in discussions on bioethics in East Asia, including China, the 'Wild East' argument figures quite prominently, i.e. the claim that, because bioethical regulations in the East are supposed to be less severe than in the West, combined with a much more technology-friendly cultural climate, Asian researchers are less hindered by bioethical bureaucracies as well as by moral scruples and fears about the possible consequences of new technologies for society or the environment. Moreover, whereas the West is dominated by the language of autonomy, individual rights and informed consent, in countries like China ‘Asian’ values are supposedly more important, and this includes Confusian values such as 'familialism'. The People's Republic of China occupies a remarkable position in the debate on Asian values, not only because of the impressive number of inhabitants of this gigantic country, but also because, on closer examination, the Asian values such as familialism are often specified as Confucian values. ${ }^{33}$. These differences between the West and the Far East seem to undermine the prospects for a universal bioethics as a complementary efforts that should accompany bioscientific and genomics developments worldwide.

From the side of the Chinese delegation, however, this picture was challenged. They argued that, although it is true that in China professional bioethics is still a relatively small-scale phenomenon, this does not mean that in their country 'anything goes'. Moreover, rather than cultivating 'Asian' values, these Chinese bioethicists are basically involved in elaborating an ethic that is quite in line with the international lingua franca, the ethics of autonomy, individual rights and informed consent. Indeed, the Chinese delegation claimed that phrases like Asian values are hardly ever mentioned in Asian debates. Renzong-Qui, who has long been an influential figure in Chinese bioethics, has argued for 'moderate ethical universalism and moderate ethical relativism' and that he 'personally... favour[s] the rights approach, because in a developing country like China, there has been a longstanding tradition in ethics that the dominant talks are duty-oriented but without rights'. ${ }^{34}$. The Bangkok declaration (1993) signed by representatives of 30 Asian governments stressed the "universality, objectivity and non-selectivity of all human rights and the need to avoid the application of double standards in the implementation of human rights and its politicisation". ${ }^{35}$ Adorno acknowledges the European origins of the human dignity and human rights framework and the sometimes 'excessive emphasis' on individual rights in the west as opposed to family and community values. However, he argues that the opposition of western and non-western values, and of universal human rights and cultural diversity, 'have lost much of their practical significance'. Non-western countries increasingly sign up to, and take part in the formulation of human rights treaties and there is sufficient flexibility in these agreements to be compatible with cultural diversity. ${ }^{36}$

Discussions such as this one are important against the backdrop of the way in which bioscience, notably genomics, is evolving. It is becoming a world-wide, global phenomenon as we said, and insofar as biotechnology and genomics are globalising, this also seems to call for an international or even global bioethics. The key question than is the extent to which the bioethical model as it has emerged under specific cultural and societal conditions in the West, can be extrapolated to others cultural realms. Can bioethics be regarded an 'export product'?

Ironically, while this discussion is evolving, the traditional bioethics model as it had emerged in the 1980s in Western countries such as the Netherlands and the UK is now increasingly under pressure in these countries themselves. Traditional 
bioethics not only involved ethical principles such as autonomy and informed consent, but also the institutionalisation and professionalisation of bioethics as a practice, in the form of bioethics experts, bioethics committees, bioethics journals, bioethics courses and bioethics research institutes. In the 1990s, however, the ethical expertmodel became challenged. The interest began to shift from formulating and applying ethical 'principles' towards developing methodologies for involving publics and societal stakeholders in bioethical debates. The ethical expert-model increasingly had to compete with more interactive strategies for science policy, based on various forms public engagement. One of the problems of the ethical expert model was that it seemed difficult to explain who the ethicists represented and on what body of knowledge their expertise was based.

To the extent that traditional bioethics is being replaced, or at least complemented, with a variety of interactive methodologies and consultations, the same question that was formulated above re-emerges. Can a more interactive approach to the various bioethical issues as it has developed in genomics and the biosciences be 'exported'? Can some of these evolving methodologies become a model for bioethical debate elsewhere? Apparently, these methodologies seem even harder to transfer that the key concepts of bioethics as such. Besides differences in terms of political systems (such as the one-party system versus a multiple party system) and communicative culture (some cultures may be regarded as "narrative" rather than "deliberative" for example), the most obvious problem is no doubt the problem of size. Compared to the Netherlands, China is an incredibly huge country, a whole world. What would public engagement or public participation mean under such conditions?

\section{Concluding remarks on formulating bioethics policies}

The UNESCO declaration aims to provide an adequate 'framework of principles and procedures to guide states in the formulation of their legislation, policies and other instruments in the field of bioethics' (article 2a). Such a document is produced following a process of worldwide consultation with representatives of member states and experts and necessarily includes some compromise and vagueness in order to achieve consensus. Its value can only be judged by its influence. For states that do not have a structure of ethical review of research or public consultation on bioethical issues, the declaration could be used as a starting point to develop such structures.

At the same time, it is clear that putting together declarations is only one way to contribute to the effort of producing a global bioethics, on the basis of dialogue. Its basic objective is to stimulate rather than to conclude or forgo bioethical deliberations. Moreover, methodologies for public engagement will no doubt become increasingly important on the international level as well. The question than becomes whether they may profit from such declarations (and vice versa) and how broader publics can become involved in declaration development.

Finally, it is clear that these types of discussion will remain rather academic as long as they take place on a rather abstract and general level. What is needed is empirical on-site research in the functioning of declarations, notably in countries where biotechnologies developments are relatively new and the institutionalisation of bioethics still finds itself in a relatively early stage of development. How will activities to promote and 'export' declaration work in practice, notably under circumstances where bioethical professionalism is still sparse? 
1. Zwart H. (2008) Challenges of Macro-ethics: Bioethics and the Transformation of Knowledge Production. Journal of Bioethical Inquiry, 5 (4), 283-293.

2. UNESCO. 2005a. Declaration on Bioethics and Human Rights http://portal.unesco.org/shs/en/ev.php-

URL_ID=1372\&URL_DO=DO_TOPIC\&URL_SECTION=201.html

3. Zwart H (2007) Statements, declarations and the problem of ethical expertise [Editorial]. Genomics, Society \& Policy. 3 (1), pp. ii-iv.

4. Landman W. and Schüklenk.U. Editorial. Developing World Bioethics Special Issue 2007. 5:3: iii-vi.

5. ibid p.iv

6. ibid p.iii

7. Human Genome Organisation (HUGO Ethics Committee http://www.hugointernational.org/comm_hugoethicscommittee.php

8. Human Genome Organisation (HUGO) Ethics Committee. 2007. HUGO Statement on Pharmacogenomics (PGx): Solidarity, Equity and Governance Genomics Society and Policy .3:1 pp.44-47.

http://www.hss.ed.ac.uk/genomics/documents/HUGOGSPVol3No12007.pdf

9. UNESCO $200332^{\text {nd }}$ Session of General Conference (32 C/Res.24)

http://portal.unesco.org/shs/en/ev.php-

URL_ID=1883\&URL_DO=DO_TOPIC\&URL_SECTION=201.html

10. UNESCO Different stages in the elaboration of the Universal Declaration on

Bioethics and Human Rights http://portal.unesco.org/shs/en/ev.php-

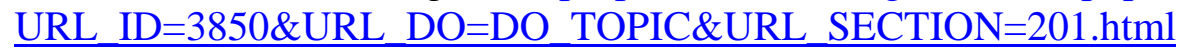

11. Landman and Schüklenk op cit p.iv.

12. UNESCO .2005b. Results of the written consultation of the $3^{\text {rd }}$ outline of the text of a declaration on universal norms on bioethics

http://portal.unesco.org/shs/en/files/7190/11062332491Consultation_en.pdf/Consultat ion_en.pdf

13 Macklin R. 2003. Editorial: Dignity is a useless concept. BMJ 327:1419-1920 http://www.bmj.com/cgi/content/full/327/7429/1419

14 Häyry M. and Takala T. 2005 Human dignity, bioethics and human rights pp.225233 p.231

15. Benatar D. 2005 The trouble with universal declarations. Developing World Bioethics Special Issue 2007. 5:3 220-224 .

Williams J. (2005) UNESCO's proposed declaration on Bioethics and Human Rightsa bland compromise Developing World Bioethics Special Issue 2007. 5:3:210-215.

16. Landman and Schüklenk op cit p.v.

17. ibid

18. ibid

19. ibid

20 Landman and Schüklenk 2005 ibid vi

21 Shetty P. 2005. UNESCO guidance on ethics and human rights slammed. Science and Development Network. http://www.scidev.net/en/health/news/unesco-guidanceon-ethics-and-human-rights-slammed.html.

See also Ten Have, H. 2006: The activities of UNESCO in the area of ethics.

Kennedy Institute of Ethics Journal 16:4 pp 333-351 and Ten Have, H.A.M.J. and Jean, M.S. (eds.) (2009): The UNESCO Universal Declaration on Bioethics and Human Rights. Background, principles and application. UNESCO Publishing, Paris.

22 Benatar 2005 op cit p.222.

23. Landman and Schüklenk 2005 op cit iv. 
24 Jing-Bao N. 2005. Cultural values embodying universal norms: a critique of a popular assumption about cultures and human rights Developing World Bioethics Special Issue 2007. 5:3 pp.251-257

See also references 32-36.

25 UNESCO Division of Ethics of Science and Technology. 2004. First meeting of the IBC Drafting Group for the Elaboration of a Declaration on Universal Norms on Bioethics. Final report p.2.

http://portal.unesco.org/shs/en/files/5700/10899699971Rap_Gred1_en.pdf/Rap_Gred 1 en.pdf

26 Rawlinson M.C. and Donchin A. 2005. The quest for universality: reflections on the universal draft declaration on Bioethics and Human Dignity. Developing World Bioethics Special Issue 2007. 5:3: 258-266.

27. Cavalli-Sforza L.L. 1994 The history and geography of human genes. Princeton: Princeton University Press.

28. European Commission 2007 Public engagement in Science. Portuguese

Presidency Conference The Future of Science and Technology in Europe, Lisbon, 810 October 2007. Report of the Science in Society Session.

Nuffield Council on Bioethics Reports and publications available at http://www.nuffieldbioethics.org/go/publications/latest_30.html

Human Fertilisation and Embryology Authority (HFEA) a statutory body that regulates fertility treatment and research. Reports of meetings and consultation reports available at http://www.hfea.gov.uk/

29. HFEA Human Fertilisation and Embryology Authority 2003 Sex selection: options for regulation para. 147 http://www.hfea.gov.uk/docs/Final_sex_selection_main_report.pdf

30. Harris J. 2005 Sex selection and regulated hatred Journal of Medical Ethics 31 pp.291-294.

31. Levitt M, Weiner K. and Goodacre J. 2005 Gene week: a novel way of consulting the public. Public Understand. Sci. 14 pp 67-79

32 Van den Belt H. and Keulartz J. (2007) Worldwide cultural differences in socioethical views in relation to biotechnology. A report commissioned by the COGEM

(Netherlands Commission on Genetic Modification)

http://www.cogem.net/ContentFiles/CGM200705\%20Worldwide\%20Cultural\%20Differences1.pdf

33.. ibid p.11

34. Renzong-Qui Bioethics in Developing Countries. Bioethics. 7:2/3 pp.108-125

Sen Amartya 1997 Human Rights and Asian Values. Sixteenth Morgenthau Memorial Lecture on Ethics \& Foreign Policy. p.118.

http://www.cceia.org/resources/publications/morgenthau/254.html/_res/id=sa_File1/2 54_sen.pdf

35. Bangkok Final Declaration of the Regional Meeting for Asia of the World Conference on Human Rights 1993 http://www.unhchr.ch/html/menu5/wcbangk.htm 36. Adorno R. 2007 Global Bioethics at UNESCO: in defence of the Universal Declaration on Bioethics and Human Rights. Journal of Medical Ethics 33 pp.150154 